\title{
Pendidikan Formal Berbasis Manajemen Mutu Sekolah (Total Quality Management)
}

\author{
Naila Fadhilah, Rusdinal, Hade Afriansyah \\ Universitas Negeri Padang \\ Indonesia
}

Email: naylaafdl27@gmail.com

\begin{abstract}
Abstrak -Education is one of the people's life goals first until now. Education it self is very implemented requires guaranteed quality quality also knowledge. Quality management is one thing which is based on the quality of education. How is quality management this will improve the quality, equality, needs and whateverRequired for the running of education with education and of course which was attended by dead people. And this quality management will affect the quality of a school it self.
\end{abstract}

Keywords: Pendidikan, kualitas mutu, sekolah

\section{Pendahuluan}

Sebagaimana yang kita ketahui bahwa pendidikan sendiri adalah usaha sadar yang dilakukan oleh manusia guna mengetahui perihal ilmu-ilmu, keterampilan serta pengetahuan guna memperkaya diri dengan pengetahuan itu sendiri maupun keterampilan-keterampilan yang berkembang dalam kehidupan dizaman modern ini. Seperti yang sudah dijelaskan oleh Ki Hajar Dewantara bahwa pendidikan adalah sebuah tuntutan pada diri seorang anak yang mana bermaksud menuntun anak tersebut mencapai kodratnya demi mencapai kebahagiaan yang semestinya.

Jadi dalam keadaan sekarang ini pendidikan sangatlah dibutuhkan. Maka dari itu untuk mewujudkan pendidikan yang bermutu tinggi sangat dibituhkan proses yang matang. Yang mana salah satu penunjang pendidikan yang baik yaitu mutu dari pendidikan itu sendiri. Disinilah akan dibahasnya bagaimana peranan mutu itu sendiri dalam pendidikan.

Dalam hal inilah total quallity management sangat berperan banyak dalam peningkatan sekolah itu sendiri agar sekolah serta semua yang ada disekolah dapat bersaing serta menyesuaikan diri dengan perubahan serta perkembangan dunia yang serba instan seperti sekarang ini. 


\section{I.METODE PENELITIAN}

Dalam penulisan artikelnya, penulis menggunakan sistem merujuk pada berbagai literatur yang tersedia. Sebelum memulai penulisan artikel ini terlebih dahulu penulisa memikirkan akan apasaja pokok-pokok pembahsan yang akan dibahas diartikelnya. Lalu penulis melanjutkan dengan pengumpulan materimateri dari berbagai sumber, sumber-sumber inilah yang akan menjadi bahan rujukan. Dan langkah selanjutnya yaitu memahami serta menuliskan apasaja yang dirasa penting dijadikan sebagai pokok pembahasan. Dan dilanjutkan dengan menyusun isi pembahasan dengan seksama. Dan yang paling penting dalam hal ini penulis juga mengidentifikasi akan makalah yang ditulisnya terlebih dahulu, disesuaikan agar sesuai dengan siapa yang akan membaca makalahnya nanti.

\section{KAJIAN TEORI DAN PEMBAHASAN}

\section{A. Pengertian Mutu Pendidikan}

Pertama tentang mutu terlebih dahulu, mutu dapa diartikan sebagai suatu ukuran yang ditetapkan dalam rangka penilaian suatu benda atau yang lainnya. Sedangkan M. N. Nasution membahas pendapatnya mengenai kualitas atau mutu yang aman menurutnya yaitu suatu syarat ukur akan kecocokan sebagai alat pemenuhan kebutuhan atau kepuasan terhadap kesesuaian yang diminta oleh si pemakai.

Pengertian mutu sendiri seperti yang telah dijelaskan oleh Marussuti(Marus Suti, 2011) yaitu bagaimana kesiapan sekolah dalam mengelola komponen-kompnen yang berkaitan dengan peningkatan kinerja sekolah secara profesional juga efisien sehingga dapat meningkatkan kredibilitas sekolah sesuai dengan syarat serta standar yang ada.

Seorang ahli Sudarwan Danim juga mengemukakan pendapatnya mengenai mutu pendidikan, yang menurutnya mutu pendidikan ini mengacu pada dampak, masukan, proses serta bagaimana hasilnya. Yang mana maksudnya yaitu bagaimana masukan yang diberikan pada kemeningkatan efektivitas pendidikan, bagaimana jalan prosesnya, bagaimana dampak yang dihasilkan serta apasaja hasil yang didapat dari itu semua.

\section{B. Indikator Mutu Pendidikan}

Dalam mutu pendidikan ini sendiri, terdapat beberapa indikator penting yang jadi pedoman atau patokan yang mana yaitu:

1) Performa yaitu aspek penting yang berkaitan dengan produk. Yang mana ini adalah salah satu karakteristik inti.

2) Kendalan maksudnya yaitu kemungkinan akan keberhasilan suatu produk pada masa tertentu. 
3) Kemampuan pelayanan atau sevice yaitu karakteristik yang berkaitan dengan pelayanan yang diberikan kepada konsumen sebagai pemakai jasa yang kita sediakan.

\section{Total Quality Management di Lembaga Pendidikan}

Manajemen mutu terpadu selain terkenal didunia pendidikan seperti saat ini juga terkenal dilingkungan perusahaan dan industri yang dapat membuktikan bahwa dengan di ikutsertakannya Manajemen mutu ini dapat menperbaiki proses serta hasil dari lingkungan ini sendiri. Jadi dapatlah disimpulkan bahwa manajemen mutu terpadu ini dapat dikatakan sebagai sebuah pendekatan yang pelaksanaannya dilakukan secara terus menerus dan difokuskan pada pengembangan agar produk yang dihasilkannya dapat disesuaikan dengan standar yang ada dan tentunya disukai oleh si pemakainya.

\section{Pembahasan}

Jika dilihat dalam segi penetapan manajemen mutu terpadu ini dalam dunia pendidikan bisa dikatan tidak dalam kondisi yang mudah untuk pelaksanaannya. Hal ini disebabkan karena dalam pengimplementasiannya didalangi juga karna ukuran roduktivitasnya yang tidak hanya berukuran kuantitatif.
Sebagaimana yang dikatakan oleh Hadari Nawari bahwa dalam dunia pendidikan ukuran produktivitasnya dapat dibedakan menjadi beberaa ukuran. Yang mana yang pertama yaitu produktivitas internal yaitu hasil-hasil yang dapat diukur secara kuantitatif dan yang kedua yaitu sebaliknya, produktivitas eksternal yang mana hasil-hasilnya tidak dapat diukur secara kuantitatif.

\section{KESIMPULAN}

Dari pembahasan yang telah diaparkan diatas dapat disimpulkan yang dimaksud dengan mutu pendidikan yaitu kesiapan sekolah dalam mengelola komponen-kompnen yang berkaitan dengan peningkatan kinerja sekolah secara profesional juga efisien sehingga dapat meningkatkan kredibilitas sekolah sesuai dengan syarat serta standar yang ada. Dan dalam segi penetapan manajemen mutu terpadu ini dalam dunia pendidikan bisa dikatan tidak dalam kondisi yang mudah untuk pelaksanaannya. Hal ini disebabkan karena dalam pengimplementasiannya didalangi juga karna ukuran roduktivitasnya yang tidak hanya berukuran kuantitatif.

\section{Daftar Pustaka}

Afriansyah, H. (2019). MANAJEMEN MUTUTERPADU.1.http://doc.org/10.17605/ OSF.IO/NRXHS 
Anonim. 2000. Manajemen Mutu Terpadu dalam Pendidikan/Kultur Sekolah. Depdiknas: Hand Out Pelatihan Calon Kepala Sekolah, Direktorat Sekolah Lanjutan Pertama.

Rusdinal, (2009). BUDAYA ORGANISASI PASCA PEMBANGUNAN DENGAN DUKUNGAN MANAJEMEN BERBASIS SEKOLAH. Pedagogi, 33(2). Retrived from http://journal.um.ac.id/index.php/ilmupendidikan/articlc/view/1200

Cravens, David W. 1996. Strategic Marketing. Jakarta: Erlangga.

Minarti, Sri. 2011. Manajemen Sekolah, Jogjakarta: Ar-Ruzz Media.
Mulyasa, E. 2003. Kurikulum Berbasis Kompetensi ; Konsep, Karakteristik, dan Implementasi. Bandung: Remaja Rosdakarya.

https://www.kompasiana.com/dianaamelia/55d84 847e8afbd2209c05ce9/manajemen-mututerpadu-dalam-pendidikan?page=all

Marus Suti. (2011). STRATEGI

PENINGKATAN MUTU DI ERA OTONOMI PENDIDIKAN. Pedadogi, Jurnal Ilmiah Ilmu Pendidikan, 3(2), 6. Retrieved from https://s3.amazonaws.com/academia.edu.doc uments/ 